\title{
Inheritance of Past Marga's Social Life in South Sumatra to Current Development
}

\author{
Meita Istianda ${ }^{1}$, Dedi Irwanto ${ }^{* 2}$, and Giyanto ${ }^{3}$
}

\author{
${ }^{1}$ Departement of State Administration, Faculty of Social and Political Science, University of Terbuka Palembang, 30137, \\ Indonesia \\ ${ }^{2}$ Departement of History Education, Faculty of Teacher and Training Education, University of Sriwijaya, 30128, Indonesia \\ ${ }^{3}$ Departement of Geography Education, Faculty of Teacher and Training Education,PGRI University of Palembang, 30116, South Sumatra, \\ Indonesia \\ ${ }^{*}$ Corresponding author. Email: dedi.irwanto@unsri.ac.id
}

\begin{abstract}
Marga's is a government system that has existed in South Sumatra society in the past. The socio-cultural wealth of the people of South Sumatra has become a special attraction for historical studies, social sciences and development policies. The occurrence of social deviations such as the emergence of the gerandong symptom along Komering Street is a sign that development policies so far have had an invisible negative effect as a result of socio-cultural and political development policies that ignore the historical roots of local communities. The purpose of this paper is to attempt to investigate the history of marga's in overcoming social problems, with a social science approach framework to find a socio-cultural policy model based on community knowledge in the East OKU region, South Sumatra. The method used is to use historical methods and qualitative methods of social science. Based on the results of the study, it can be seen that in the past the marga's community was able to have a better social life. This social integration is maintained in the form of rules of life and marga's government with higher social sanctions than legal sanctions. The development carried out by marga's in East OKU has inserted a lot of ownership rights to the members of the marga's, so that the sense of guarding and inheritance is stronger. Reproduction must be carried out in the form of a variety of socio-physical development as it can be a practical contribution for the current political authorities in making public policy.
\end{abstract}

Keywords: Marga's, Historical method, Socio-cultural development, cultural reproduction

\section{INTRODUCTION}

The current development activities in remote parts of the country gives all people, especially those in South Sumatra, great hope for quick development and increased openness. Unfortunately, the development that occurred remained a mere hope rather than a sustainable independent development pendulum because it was unable to generate community engagement.

This development model is structured to produce at least homogeneous populist leaders (right populists), rather than an idealistic solution to the dilemma at the local level, and instead produces a large number of antagonistic populist leaders (left populists). In the eyes of rural people, crisis management is important for addressing democracy programs. [1, 2, 3] These left populist leaders typically act as brokers or brokers (makelar) by posing as persons who reflect the exclusive will of legitimate rulers. [4]

The reform order (orde reformasi) had great aspirations for a return to local politics, particularly at the lowest level, the village, which had a decentralized system. The development and rise of local leaders, brokers who self- identify as left populist in practice, continue to present a centralized approach. These left populist middlemen are, in fact, local elite leaders acting in plain sight. Many are placed in positions above the local village head (kepala desa or kades) to create programs conducted by the village on behalf of the local government or commands from local political officials. [5]

That is, the village community does not compile the bottom-up rural development model, that this reform directive promises. However, these left populist brokers continue to make deals based on what the client wants, whether it's from the federal government, state governments, political parties, or the private sector. This situation appears to be the result of the village community's decision, but in reality, the brokers in the reform order's decentralization were allowed to lead and activate what is called [6] with the word as if the desires of the village community to exercise their authority over their daily lives and collective destiny, even if structurally they composed it. 
Local political settings, such as those described by [7] and [8], in which brokers act as brokers for regional leaders and local politicians, have resulted in an epidemic that tends to exclude politically weaker groups. This circumstance has also resulted in the abolition of idealistic radical groups in the village, which were fighting for the basic issues of cultural identity's economic, social, and political status, as well as the economic inequalities of their village ethnicity.

As a result of such issues, the inhabitants of South Sumatra, who have traditionally and historically lived in groups with a genealogical and territorial link known as marga's, have become more aware. This circumstance not only transforms the political system, but it also has a significant impact on the elimination of local values in the viewpoint of community leaders. $[9,10]$

This study makes an attempt to address this issue by posing a series of questions. What is the state of the marga's socio-political existence, particularly pesirah's populist policies? Why is this nostalgic populism suddenly developing in the South Sumatra community? Was politics at the local level having a negative impact during the New Order and the Reformation Order? Is this due to a disconnect between the past and contemporary political legacies? What is the true cost of today's rising populist xenophobia in local government?

\section{METHODS}

This study employs both historical and qualitative methodologies to arrive at authoritative conclusions. The historical approach for revealing the past of daily life in the marga's, particularly the populist leadership pattern of the pesirah, the marga's head. Understanding local leadership patterns at the village level in South Sumatra today is done through qualitative methodologies. Qualitative approaches are meant to capture reality across a broad and complicated spectrum, allowing them to solve issues in comparing research questions in depth and detail. [11]

The literature review and field interviews were employed to acquire data for this paper's analysis. Local political realities in South Sumatran villages that continue to change are discussed by examining local politics in the post-colonial, New Order, and post-New Order eras. Literature sources are selected selectively so that the analysis can describe the actual situation or condition in accordance with the focus that has been set, especially discussing the local political realities in South Sumatran villages that continue to change by examining local politics in the post-colonial, New Order, and post-New Order eras.

From the New Order to the Reformation Order, the sites in this study extensively explore colonial and post-colonial South Sumatra. However, the focus of this study is the Ogan Komering Ulu Timur Regency, which is one of South Sumatra's cities and regencies. The present idea of locality remains the same, despite the fact that it cannot be generalized.

\section{RESULT AND DISCUSSION}

\subsection{Local Leaders' Marga's Dysfunction and Populist Politics}

The first section of this study will discuss three things to highlight the marga's function and dysfunction in the institutional framework of the village community in South Sumatra until the emergence of various types of populist politics by local leaders. First, our research suggests that marga's in South Sumatra are political entities. In this case, a brief overview of the marga's history in South Sumatra from the colonial to the post-colonial periods would highlight how the marga's, particularly its leadership pesirah, is responsible for the marga's diverse interests. Furthermore, the researcher acquired data from interviews with internal actors in regards to the findings of the most recent study, particularly when the process of transforming marga's dysfunction in institutional terms was in progress, particularly during the New Order era in the 1980-s.

Second, this study aims to explain in more depth the transformation of marga's s into sub-districts or villages, which are subsequently incorporated into new sub-districts, based on a case that occurred during the institutional transformation of marga's dysfunction. When the process of centralization and modernization of villages in the exmarga's is included in the analysis and discussion of this study, it is important to review the political behavior of the state and local marga's, because of important role of these two structures is the central point of the process of transforming marga's dysfunction. The existence of the state, or center, in the daily social order of the marga's is connected with the existence of local government at the local level, while the collective memory of pesirah populist politics in the exmarga's in South Sumatra is progressively disintegrating and vanishing.

Third, this research looks at how everyday life has changed under the present Reformation Order, which aims to reform the order of local institutions and leadership at the grassroots level. On the one hand, decentralization was reapplied at the local, sub-district, and village levels in the exmarga's of South Sumatra during this third step. At the same time, the populist leadership pattern at the municipal level is swinging the pendulum in the opposite direction. With decentralization, the dualism of marga's life in the past resurfaced, and institutionally, the ex-sub-districts marga's and villages reverted to the past.

The pattern of leadership, on the other hand, uproots and alienates the genuine roots of the pesirah's function as a local leader at the local political level, distancing the ex-marga community from their local leaders, village heads, sub-district heads, and regents. In order to determine where the exmarga's community stands in the ongoing contestation arena, dualism as a type of institutional re-inheritance and local politics of prior leaders become highly relevant in this discussion. 


\subsection{Marga's Life in South Sumatra: Decentralization and the Pesirah Populist Pattern}

The marga's has existed in South Sumatra as a political governance entity since the Palembang Kingdom was created in 1552 by Ki Gede Sido Ing Suro Tua. During Sultan Abdurrahman Khalifatul Mukminin Sayidul Imam's establishment of the Palembang Sultanate in 1659, the marga's authority was reorganized once more. Furthermore, when the Dutch took control of Palembang in 1821, they continued to adopt it, as did Japan until post-colonial times in 1983. [12]

As a result, marga's analysis, as a governance institution, is concerned not just with administration and bureaucracy, but also with the local political patterns that come from this governance, including people's political conduct. Originally, the marga's was a genealogically bound territory, but it was turned to an administrative territorial area by the Dutch. Despite the fact that it has been officially transformed into a geographical boundary, its genealogical essence remains the foundation.

The Dutch also did not replace the marga's leadership with a pesirah, ensuring that the marga's socio-cultural roots as a community organization remained intact. In terms of institutional organization, the marga's is made up of numerous hamlets (dusun) managed by a kerio, particularly the hamlet (dusun) that serves as the marga's capital and is governed by the pembarap, who also serves as the pesirah's spokesperson. There are multiple settlements beneath the hamlet (dusun) which are called the kampung, each led by a pengawo. A marga's genealogical relationships are usually formed by a group of descendants, clans, or lineages descended from the same puyang (ancestor).

The pesirah, with the help of the pembarap's and the kerio's, is in charge of the marga's leadership's local politics. The Dutch attempted to transform this style of leadership from a single leader to a collegial leader around the turn of the twentieth century by founding a marga's council. This model, however, is ineffective since the pesirah's role as head of the marga's council remains significant. [13] The Netherlands, on the other hand, published the marga'sordonatie in 1915, which granted the marga's more autonomy within the context of ethical politics. Even in the Dutch decentralization study at the time, the marga's community's participation in decision-making was becoming increasingly limited. On the other hand, the role of pesirah's is expanding, giving it a larger populist presence in people's minds.

Because a pesirah's may turn populist features into participatory populists who can be oriented to the practice of organizing their citizens in the everyday public action space, this significant power of pesirah's gives rewards to the people. With the Dutch government as a prospective partner for a pesirah, pesirah's and the marga's council (dewan marga) were able to influence several economic institutions. A pesirah's alibi for prospering his marga's is the acquisition of marga's riches. The marga's cash deposit surplus was used for collective action in the interests of the community, which he perceived to be helpless at the time.

The Marga Cempaka in Onderafdeeling KomeringOeloe, led by Pangeran Mohammad Saleh, is an unusual case since he not only acts as a great man and a rich guy for his marga. [13] Pangeran Mohammad Saleh, on the other hand, was able to carry out retributive populist activities, such as erecting modern marketplaces in the dusun of Cempaka and Campang Tiga, as well as offices and marga halls. Pangeran Mohammad Saleh also established a local rubber factory through trading links with D. J. G. Van Setten, a Dutch agricultural expert.

According to thesis [14], Pangeran Mohammad Saleh's redistributive populist deed is a progressive endeavor to govern his marga community's market economy in order to establish a fair market economy system. According to [15], the market economy of Pangeran Mohammad Saleh's sandy redistributive populist actions will culminate in the formation of a society in which everyone benefits when everyone benefits. During the harvest season, Pangeran Mohammad Saleh also loaned his clansmen interest-free loans to pay their laborers so that they would not be taken advantage of by Chinese loan sharks from Palembang.

This action not only demonstrates the pesirah's trading spirit, but also serves as an aspirational populist action, demonstrating the pesirah Pangeran Mohammad Saleh's ability to exercise local political power over his marga's community's collective daily life by manifesting it in an effort to reverse the marga community's depleting economic condition.

The nature of local politics around Pangeran Mohammad Saleh's resignation exemplifies pluralist populist behavior. According to [16 \& 17], this action is a way of acknowledging the community's fundamental needs as a crucial link in the never-ending labor of emancipation, involving all groups, particularly those who feel threatened. This pluralist populist act is also a bold political solution endeavor, aimed at democratically addressing the daily economic challenges that their marga's members experience.

This right populist move, which was subsequently emulated by many other pesirah's in other marga's in South Sumatra, elevated pesirah's to the status of "large men" who were adored alongside their puyang (ancestor). This idealistic act is carried out by these pesirah with the primary goal of achieving the power of adat and the power of personal achievement among their marga's followers. Right populist activities, such as those taken by Pangeran Mohammad Saleh, have raised intellectual awareness among his marga's members.

The people of Marga Cempaka have been one of the Komering ethnic groups with a strong awareness of going to school since the early days of implementing the ethical policy that opened colonial schools in Palembang. This trend continues today, with persons from this ethnic group occupying the majority of government positions at the 
regional level in South Sumatra, including governors, heads of services, and public employees.

\subsection{Marga's Abolition During the New Order: The End of Right Populist Actions in Village Communities}

Marga's in South Sumatra were preserved until postcolonial era. Although, he claims, resistance arose at the dawn of statehood, particularly during the Old Order, because the state saw marga's as colonial products. Some of the legal items employed by the marga's administration, like as courts, land governance norms, and so on, are still according to colonial-era laws. [18]

The pesirah's of each marga's at the time was structured similarly to that of the colonial period, with duty to the subdistrict head (camat). The pesirah's post is elected by the community directly every five years and inaugurated by the regent on behalf of the governor, who is accompanied by Muspida and DPRD members. Pesirah's also receives a wage from the local government in the form of a monthly gift of 10.000 IDR, which is paid every three months. The beneficiary's income also comes from $15 \%$ of the commission for "customary fees" sources including yard taxes, houses, rice fields, fields, gardens, forests, cattle, rivers, lebak, fees for marital affairs, divorce, reconciliation, violation of customs, and crimes like murder. In the form of IPEDA, this money goes to the local government's coffers (Regional Development Contribution). [19]

Administratively, the pesirah's administration was established as an intermediary (broker) under the sub-district head (camat) during the Old Order and the beginning of the New Order. As a result, the sub-district head (camat) does not need to go directly to face kerio's, proatin's, or pengawo's since pesirah's will take care of it. The status of pesirah's is still very important at this time since the marga's community still respects it. Although titles such as pangeran or dipati that were awarded to pesirah's during the colonial period have been withdrawn, traditional titles such as Mangkualam, Singadikane, Singadilaga, and others can still be carried by the pesirah's.

During the New Order era, major marga's changes happened. The centralized government structure of the New Order enacted Law Number 5 in 1975, which was followed by Government Regulation Number 5 in 1979, further consolidating pesirah's status. With the issuing of the Governor's Decree dated March 1, 1983, marga's were completely abolished. The delay in making a judgment following the enactment of Law Number 5 of 1975 and Government Regulation Number 5 of 1979 was due to the new system of using village chiefs (kepala desa) as a substitute for the pesirah's, which still needed to be adjusted. [19]

All pesirah in South Sumatra assembled on March 1, 1983, with roughly 500 pesirah's in attendance. The pilgrims were paid a severance payment of 100.000 IDR, effectively ending the marga's structure in South Sumatra. The village head takes the role of the pesirah, the kerio or proatin takes the place of the hamlet head (kepala dusun or kadus), and the pengawo is abolished. With the increasing penetration of the state into local government at the lowest level to the village, the New Order's centralism transformed not only the form of the marga's to the village (desa), but also the system, direction, and philosophy of the marga's. The village head system, which replaced the pesirah, weakened the authority of adat members at the local level more and. Some of them, such as getting up (timbang bangun), washing the hamlet (tepung dusun), tekap malu, and tepung tawar, remained at first. [20] This customary rule, on the other hand, is more than just ceremonial with a weak binding effect.

The shift in South Sumatra's governance system from marga's to village governments has various cultural ramifications. Desanization, which has replaced the marga's, has weakened the marga's cultural identity by severing genealogical ties. In the views of the community, the village head's (kepala desa or kades) position is becoming less legitimate, and his position is becoming less equivalent to that of the pesirah's. Because the state has characterized the village head as an extension of the government's arm to control the community, the roles and obligations of the village head have changed at will. The village could not be a representative of the people's interests under the New Order (orde baru) totalitarian administration.

In South Sumatra, the replacement of marga's by villages resulted in the pesirah's populist politics being replaced by the populist politics of the village head (kades). As the New Order government's long arm, the village chief evolved an authoritarian populist pattern. For authoritarian populism, which backs transgressive strongman leaders and is willing to carry out political beliefs that uphold traditional values for the state's unity. [7, 21] The view [22] of putting up the rule of state constitutional law, which occasionally commits and utilizes performative violence to display political will and domestic authority, is the same as the authoritarian populism of the village head (kades) who replaces the post of the pesirah's.

This means that in his approach to villagers, the village head tends to distinguish between illiberal and democratic techniques in order to maintain village order. The village chief values the power of the large people above him more than the great power of his hamlet's grassroots. As a result, in rural South Sumatra, the prior populist paradigm of pesirah democracy, which saw grassroots from the bottom up and organized its marga's community to fight against big power, began to fade. 


\subsection{Desire for Inheritance: Nostalgic Populists' Collective Memory of the Marga's in Village Community of Local Leadership in the Time of Reformation Order}

In comparison to West Sumatra, when the centralized New Order system collapsed, West Sumatra responded rapidly to the development of a nagari's, as it had in the past. Meanwhile, in South Sumatra, marga's are being restored in a rather peaceful manner, both as a cultural spirit and as a means of showcasing local identities that have existed since the colonial period until the early days of the New Order. Under the emergence of the Reform Order's decentralized character, the marga's of the past in South Sumatra remain immersed.

The inability to maintain traditional institutions in South Sumatra has weakened socio-cultural life, which is still continuing under the control of local government agencies under the Reformation Order. The ethical control that was central to customary institutions throughout the marga's era remained unchanged, but it took on a new shape that was distinct from that of the previous New Order era. Local government in rural South Sumatra has become a battleground for local elite political vehicles to further their political and economic interests, which compete not only on a regional but also on a national level.

These local elites became local strongmen during the Reformation Order as a result of their role in regional autonomy, both through regional head elections (pemilihan kepala daerah langsung or pilkada) and regional enlargement (pemekaran daerah), which signaled a transition in local politics from the former time. Before Suharto's fall, the role of local strong individuals, especially economic rulers, could no longer be contained in the open of reformation era. Those with power and money (economic boss) profit the most from the current reform period. Local strong people who dominate local executives and executives in this area are able to place their hands (kaki tangan) on the local political system in rural South Sumatra and indirectly regulate it.

Decentralization in South Sumatra has not only led in mindless growth, but it has also weakened social bonds in rural areas. Few rural populations are aware of their rights to engage in political and governance processes in their communities. At the rural level, central programs running through local executive and legislative elites in the regions cannot provide self-sustaining development and development. Because the model of leadership and oversight is structured through brokers developed by local executive and legislative elites, rather than through the desires of the village community itself. These brokers are formed to carry out electoral populist activities as a means of formulating policies for rural economic projects.

The participation in this project refers to people who are not critical and have support connections with local electoral populist figures for the benefit of the community, according to research [23] of rural forest initiatives in South Sumatra as well as studies [24, 25] in agriculture, their political personalities' or parties' voices. As a consequence, persons who are unaffiliated with electoral populist agendas will be unaffected by the programs that are being implemented. In this system, the brokers who were on the grassroot in rural South Sumatra to carry out ordered projects also carried out exclusive populist actions with an anti-pluralist slant, emphasizing that the policies of rural community development projects represented the sole will of the local elites above them, with no attempt to create legitimate economic competition. They indicate that anyone who does not support the party that receive the quote from this rural initiative is not a proper member of the people, or rural community.

In South Sumatra, the current populist local leadership is becoming increasingly chaotic. In the past, the village head served (kades) as a stand-in for the pesirah's, but now he serves as a partner to brokers, local academics, instructors, and lecturers who were developed by and are affiliated to the regional executive and legislative elites. In addition to the lack of older characters with right populist knowledge, younger figures from dynastic politics are more likely to arise with leftist populist views. [2] This crisis was triggered by the intervention of outsiders in rural South Sumatra, which was quite limited at the time of the marga's.

The regional brokers, who are formed by the executive and legislative elites, act as populist libertarians, blaming inefficient village administration and xenophobic populists who see rural communities as culturally and ethnically homogeneous totalities for rural policy decisions. These brokers are quite often from outside the neighborhood and present themselves as reckless experts, but whether the project proceeds or not is an another story. As a result, rural communities become welfare receivers that rely on their projects and are only symptomatic for a short time.

In rural South Sumatra, community decentralization is more obvious than the anti-centralistic form of the New Order era. However, this decentralization is more about "releasing the head of the snake while keeping the tail tied", resulting in a significant reliance on central government laws and projects in rural South Sumatra. In terms of customary institutions, during the decentralization period of the Reformation Order, what appears to be the widest potential for province and local governments in South Sumatra to build their own policy arrangements on local customs and values. Rural communities in South Sumatra, on the other hand, as exmarga's, believe that the government is unable to meet their needs in the face of the country's penetration by large-scale economic and political interests, which jeopardize the environment of rural communities.

Attempts to locate the inheritance of right populist deeds in the marga's era in the eyes of rural populations are more than romantic. They believe that what the marga's has inherited and the leftist populist pesirah in the marga's life will be able to restore the marga's economic and political interests. They hope that if the function of the marga's spirit 
and the actions of the past's right populists can be present in today's life, amidst the winds of reformation, the various burdens of physical development can be maintained within the framework of local noble ethics and customs that are longterm in favor of the village community's interests, not just for the moment.

The current increase in the amount of village funds (dana desa) available, if managed by a populist lefty, will be able to properly empower and make the village community selfsufficient. Nursery and reforestation forestry initiatives are capable of not only delivering and planting seeds, but also of maintaining and creating long-term economic prosperity for them. [24] Agricultural projects that provide agricultural facilities and infrastructure, on the other hand, must not only modernize all of their agricultural world, but must also become self-sufficient and expand their food supply. [25] One of the prerequisites is to reestablish the marga's life, or at least the presence of the spirits of the pesirah, the rural community of ex-marga's in South Sumatra, who had a right populist attitude, full of aspirational populist activities, pluralist populists, retributive populists who stood with them. It is definitely will further build cultural cooperation between the people [26].

\section{CONCLUSION AND RECOMMENDATIONS}

According to the findings, the first phase of marga's-tovillage transformation in South Sumatra involved not only a shift in institutional status, but also a transformation in system, orientation, and philosophy in the lives of ex-marga's rural communities. Villages in the New Order era have abolished the pesirah's right's populist spirit and replaced it with the village head's (kades) left populist acts, attributable to centralized government and modernization of the lowest level local government organizations. As a result, the marga's cultural identity was harmed as a result of the desanization that occurred in South Sumatra, which broke down genealogical ties.

The village head (kades) is more evolving and becoming authoritarian populists than aspirational populists, culminating in the village head losing legitimacy in the eyes of the community and becoming a tool of the government to control the community. Local village leaders in South Sumatra, under the New Order authoritarian regime, have put the village as the representative of the people's interests in the authoritarian populist act.

Furthermore, when the Reform Order era's decentralization took place today, it turned out to be less productive in the old marga's rural villages in South Sumatra. Local elites, executives, and legislatures that arose as a result of regional elections and regional expansion were able to become "local strongmen" who were able to reach the countryside. Through the role of the brokers they created and were close to, they co-opted and imprisoned the local village chief. Starting from arranging, managing, and controlling every fund and project that flows to the villages of ex-marga's in South Sumatra, these brokers work tactically hidden and neat in quiet. Meanwhile, electoral populist acts swept through the countryside, quickly determining who and which were the people in the village, those who supported the local elite, and those who supported the parties that would receive a quote for every incoming rural project.

Interestingly, the village chief (kades) became obedient to this clique of brokers, as well as a sycophant for the government's interest, without regards for the people's aspirations. Today's brokers come from outside village figures who do nothing more than populist xenophobic acts, seeing the village communities they foster as a totality of unity, similar and undifferentiated cultures and ethnicities, and who cross the roles of parents, jurai's (tetua desa), and local traditional leaders. These brokers come from outside the village community and sometimes portray themselves as irresponsible experts, but whether the project proceeds or not is a different story. As a result, rural communities become welfare beneficiaries, reliant on their projects and suffering from transient symptoms.

This research proposed that a quick attempt be made to reestablish marga's life, not only as a form of romanticism, but also to restore the left populist soul and spirit that has supported the values and aims of the ex-marga's village communities in South Sumatra. In the current period of decentralization reform, the negative effects of the rural development model in South Sumatra would increasingly remove the existence of local ethics and values in rural development. Physical development must be able to be followed by cultural development based on local customs and genealogy to maintain pace with current physical development. So that this physical development is not in vain and, in the long run, can give significant benefits to the $e x$ marga's village community's long-term independence in South Sumatra.

\section{ACKNOWLEDGMENTS}

The publication of this article was funded by Hibah of Public Service Agency of Universitas Terbuka 2021 Applied Research Scheme (Skema Penelitian Terapan)

\section{REFERENCES}

[1] D. Woods, Populism in search of its model, Chinese Political Science Review 2(3)(2017) 25-265. DOI: https://doi.org/10.1007/s41111-017-0067-X

[2] J. P. Gagnon, E. Beausoleil, K-M. Son, C. Arguelles, P. Chalaye, C. N. Johnston, What is populism? Who is the populist?, Democratic Theory 5(2)(2018) 6-26. DOI:https://doi.org/10.3167/dt.2018.050201

[3] A. Dzur, C. M. Hendriks, Thick populism: democracyenhancing popular participation, Policy Studies 39(3) (2018) 1-18.

[4] S J. W. Muller. J.W. Muller, Parsing populism: Who us and who is nit a populist these days?, Juncture, 22(2) 
(2015) 80-89. DOI: https://doi.org/10.1111/j.20505876.2015.00842.x

[5] S. Sailela, R. A. Damayanti, Village development planing discussion in Indonesia: Is it working?, Proceeding ICAME 2018, Makassar, Nov. 5th, 2018. DOI: https://doi.org/10.2991/icame-18.2019.30

[6] T. Riofrancos, Populism's power, Perspectivse on Politics 15(03)(2017) 865-867. DOI: $10.1017 / \mathrm{S} 1537592717001542$

[7] D. Filc, Post-populism: explaining neo-liberal populism through the habitus, Journal of Poliical Ideologies 16(2)(2011) 221-238. DOI: https://doi.org/10.1080/13569317.2011.575685

[8] I. Yilmaz, N. Morieson, A systematic Literature review of populism, religion and emotions, Religions 12(272) (2021) 1-22 DOI: https://doi.org/10.3390/rel120402722

[9] Wasino, Indonesia: from pluralism to multicultural, $\begin{array}{llll}\text { Paramita } & 23(2) & \text { (2013) } & 148-155\end{array}$ DOI: https://doi.org/10.15294/paramita.v23i2.2665

[10] M. Haboddin, Populisme, politik pertahanan, dan pemimpin lokal, Jurnal Inovasi Sosial dan Politik 1(2)(2019) $173-180$

DOI: https://doi.org/10.33474/jisop.v1i2.4802

[11] K. Morrison, What is qualitative research?, an International Journal on Tehory adn Practice, 20( 4)(2014) 328-329.

[12] F. Amran, Kesultanan Palembang dalam pusaran konflik (1804-1825), Bijdragen tot de Taal-, Land- en Volkenkunde, 176( 2-3) (2020) 442-444 DOI: https://doi.org/10.1163/22134379-176020144

[13] D. Irwanto, Melaise dan lambang kekayaan ekonomi penguasa lokal di Palembang, 1929-1942, Lembaran Sejarah, 13(1)(2017) 48-71 DOI: https://doi.org/10.22146/lembaran-sejarah.335111

[14] L. Quaglia, The "old" and "new" politics of financial services regulation in the European Union, New Political Economy 17(4)(2012) 515-535 DOI: https://doi.org/10.1080/13563467.2012.622360

[15] P. Frazer, When everybody does better: building a movement for chang, Griffith Review 57(2017) 70-79

[16] Y. Stavrakakis, The Return of "the People": Populism and anti-populism in the shadow of the European crisis, Constellations, 21(4)(2014) 505-517 DOI: https://doi.org/10.1111/1467-8675.12127

[17] G. Markou, The Rise of Inclusionary Populism in Europe, Comtemporary Southeastern Europa 4(1)(2017) 1-19.

[18] A. Reid, The Indian dimension of Aceh and Sumatra History, Journal of Maritime Studies and National Integration 4(2) (2020) 64-72. DOI: https://doi.org/ 10.14710/jmsni.v4i2.86399

[19] J. A. C. Vel, A. W. Bedner, Decentralisation and village governance in Indonesia: the return to the nagari and the
2014 Village Law, The Journal of Legal Pluralism and Unofficial Law 47(3)(2015) 493-507. DOI: https://doi.org/10.1080/07329113.2015.110937

[20] K.N. Abdullah, H. Sofyan, I. Rumesten, T. Pasyah, Functionalization of the village head as customary leader in the social field in South Sumatra, Brawijaya Law Journal 7(1)(2020) 57-69. DOI: https://dx.doi.org/10.21776/ub.blj.2020.007.01.04

[21] K. A. Sengul, Populism, democracy, political style and post-truth: issues for communication research. Communication Research and Practice 5(1)(2019) 1-14. DOI: https://doi.org/10.1080/22041451.2019.1561399

[22] M. Mietzner, Fighting illiberalism with illiberalism: Islamist populism and democratic deconsolidation in indonesia, Pacific Affairs 91(2)(2018) 261-281. DOI: https://doi.org/10.5509/2018912261.

[23] Mulyanto, The sonor farming traditional on forest and land fire in Ogan Komering Ilir Regency South Sumatra. Proc. of the international conference of Social Science and character education, 2019, DOI:10.2991/icossceicsmc-18.2019.25

[24] S. Widodo. A critical review of Indonesia'a agrarian reform policy, Journal of Regional and City Planning 28(3)(2017) 20-24 DOI:10.5614/jrcp.2017.28.3.4

[25] D. E. Gilbert, Laborers becoming "peasant": agroecological politics i Sumatran plantation zone. Journal of Peasant Studies, 47(5)(2020) 1030-1051 DOI: https://doi.org/10.1080/03066150.2019.1602521

[26] Yuniarto, R. (2021). Opportunities and Challenges of Socio-Cultural Cooperation in China's Belt and Road Initiative in Indonesia. Jurnal Hubungan Internasional, 9(2), 98-111. doi:https://doi.org/10.18196/jhi.v9i2.8232 